\title{
Prevalence of Epizootic Lymphangitis and Bodily Distribution of Lesions in Cart-Mules in Bahir Dar Town, Northwest Ethiopia
}

Demeke Meselu $^{1}$, Rahmeto Abebe ${ }^{2^{*}}$ and Berhanu Mekibib ${ }^{2}$

${ }^{1}$ Livestock and Fisheries Bureau, Amhara Region, Bahir Dar, Ethiopia

${ }^{2}$ School of Veterinary Medicine, Hawassa University, PO Box 05, Hawassa, Ethiopia

"Corresponding author: Rahmeto Abebe, School of Veterinary Medicine, Hawassa University, PO Box 05, Hawassa, Ethiopia, Tel: +251 911541384; E-mail: rahmetoabe@gmail.com

Rec date: December 15, 2017; Acc date: January 23, 2018; Pub date: January 24, 2018

Copyright: (c) 2018 Meselu D, et al. This is an open-access article distributed under the terms of the Creative Commons Attribution License, which permits unrestricted use, distribution, and reproduction in any medium, provided the original author and source are credited.

\begin{abstract}
Epizootic lymphangitis (EL) is a debilitating equine disease that in its classical form is characterized by chronic discharging cutaneous nodules. The disease has been reported to be endemic in Ethiopia, a country where equids provide a vital utility and source of income to many people in resource-poor settings. This study was conducted in Bahir Dar town, Northwest Ethiopia to investigate the prevalence, risk factors and bodily distribution of lesions of EL in cart-mules. To this effect, both clinical and microscopic examinations were made on a total of 402 mules and an overall prevalence of $32.84 \%(132 / 402)$ was recorded. The mules had nodular, ulcerative pyogranulomatous lesions following the lymphatic lines of the legs $(79.6 \%)$, on their neck $(9.85 \%)$, around the inguinal area $(6.82 \%)$, on their back $(2.27 \%)$ and on their perineum $(1.52 \%)$. None of the risk factors considered (sex, body condition score, use of harness, and presence of wound prior to the disease) were noted to be significantly associated with the presence of EL on mules $(p>0.05)$. Moreover, $34 \%$ of the cart-mule owners were reported not to allow mules affected with EL offwork even for a single day. In conclusion, the present study has revealed a high prevalence of EL in mules and it is the second work in Ethiopia disproving the assumption that mules are resistant to the disease. Thus, early detection of the disease and treatment with effective drugs and restriction of movement of affected animals is recommended to prevent the spread of the disease to unaffected equids. Also, future studies are required to find out the factors predisposing mules to $\mathrm{EL}$.
\end{abstract}

Keywords: Bahir Dar; Cart-mules; Ethiopia; Epizootic lymphangitis; Lesions; Prevalence

\section{Introduction}

Epizootic lymphangitis (EL) is a contagious, chronic disease of horses, mules and donkeys characterized clinically by a spreading, suppurative, ulcerating pyogranulomatous dermatitis and lymphangitis. It is caused by dimorphic fungus currently known as Histoplasma capsulatum var. farciminosum [1,2]. Transmission is by wound infection or blood sucking insects [3].

Clinically EL has been described to occur in four forms: ocular, cutaneous, respiratory, and asymptomatic carriers. However, the cutaneous form is the most common [4]. Mixed clinical presentations can occur and may reflect different stages of disease progression. Chronic disease results in progressive lameness and severe debilitation which may be a result of multi-systemic involvement [5].

Epizootic lymphangitis is endemic in west, north, and northeast Africa, the Middle East, India, and the Far East. The disease is currently prevalent in Ethiopia, particularly it is endemic in humid and hot areas located at an altitude of 1500 to 2300 m.a.s.l [6]. Depending on the region, the prevalence of EL in horses varied from 18.8 to $26.2 \%$ [6-10]. However all of these studies focused on horses only and didn't give attention to mules, which are equally valuable animals as horses for the rural communities. There is only a single study of EL in mules in Ethiopia [11], which to the authors' knowledge, is the only field study of the disease in mules globally. Thus, this study was initiated to bridge the information gap about the disease in mules both locally and globally. The study was aimed to estimate the prevalence of EL in cartpulling mules, identify the potential risk factors and assess the bodily distribution of lesions.

\section{Materials and Methods}

\section{Description of study area}

The study was conducted in Bahir Dar town, Northwest of Ethiopia. The town is located at about $554 \mathrm{~km}$ away from Addis Ababa along the upper Blue Nile river basin. The area has an altitude ranging from 1600-1800 m.a.s.l. [12], receives an annual rainfall of $1500 \mathrm{~mm}$ and experiences a lower and higher average temperature of $10^{\circ} \mathrm{C}$ and $30^{\circ} \mathrm{C}$, respectively. The major livestock population of the area consists of 7,839 cattle, 23,463 Goats and sheep, 12,528 equine and 62,012 poultry. The major farming system of the area is mixed crop livestock system [13].

\section{Study population and sampling}

The study populations were cart pulling mules found in Bahir Dar town. After identification of the gathering points of cart-mules (flour mills, construction sites, market places, cart stations), all animals found in the town $(n=402)$ were included in the study. Cart stations were visited two times in a day, in the morning and afternoon, to examine the two mules that were used to pull a single cart in shifts. To avoid re-sampling, maximum effort was made to identify each mule by color, owner's name and cart number. 
Page 2 of 4

\section{Clinical examination of mules}

The disease was tentatively diagnosed by clinical examination including visual inspection and palpation for the characteristic lesions (presence of nodules and/or ulcers). Each mule was thoroughly examined for one or other forms of the disease with special emphasis on the cutaneous form. During clinical examination, sex, body condition score, working status, number of mules owned by the cart owner/driver and bodily distribution of EL lesions were recorded. The body condition score (BCS) of the mules was assessed and categorized as "poor", "medium" and "good" according to Svendsen [14].

\section{Microscopic examination}

Clinically positive horses (horses with either nodules or ulcers of EP) were subjected to further laboratory examination. Depending on the size and consistency of the presented skin and subcutaneous nodules or proliferative lesions, fine needle aspiration (FNA) was performed using a standard syringe $(5 \mathrm{ml})$ and needle $(22$ and 23 gauge) with aspiration technique. Briefly, after disinfecting the area (preferably intact nodules) with alcohol swab, the needle was inserted into the nodule and then redirected, while continuously applying negative pressure. The material collected was then transferred to a clean glass microscope slide and then blood smearing technique was used for smear preparation. The smears were allowed to dry quickly at room temperature. Dried smears were wrapped with clean and dry paper and transported to the Bahar Dar regional veterinary lab and stained with Gram's and Giemsa stains. The stained smears were examined under oil immersion magnification for the presence of the organism $[15,16]$.

\section{Data management and analysis}

The data collected during the study period was recorded into Microsoft Excel spreadsheet and encoded. Statistical analysis was carried out using STATA software version 11 (STATA corp., College Station, TX). The association between the prevalence of epizootic lymphangitis and the hypothesized risk factors was analyzed by $\chi^{2}$ independent test. In all the cases, 95\% confidence level was set and pvalue $<0.05$ was taken as significant.

\section{Results}

Out of the total of 402 cart mules examined, 132 (32.84\%) were found to have epizootic lymphangitis. The prevalence of EL did not have a significant association $(p>0.05)$ with any of the variables considered as risk factors (sex, BCS, use of harness, and presence of wound before the development of EL) (Table 1).

\begin{tabular}{|l|l|l|l|l|l|l|}
\hline $\begin{array}{l}\text { Risk } \\
\text { factors }\end{array}$ & $\begin{array}{l}\text { No of } \\
\text { mules } \\
\text { examined }\end{array}$ & $\begin{array}{l}\text { No of } \\
\text { EP } \\
\text { cases }\end{array}$ & $\begin{array}{l}\text { Prevalence } \\
(\%)\end{array}$ & $\mathbf{9 5 \%} \mathbf{C l}$ & $\mathbf{X}^{2}$ & $\mathbf{p}$ \\
\hline Sex & & 38 & 34.2 & $25.3-43.1$ & & \\
\hline Female & 111 & 94 & 32.3 & $26.9-37.7$ & 0.14 & 0.71 \\
\hline Male & 291 & & & & & \\
\hline BCS & & 50 & 28.7 & $21.9-35.5$ & & \\
\hline Poor & 174 & 53 & 36.3 & $28.5-44.2$ & & \\
\hline Medium & 146 & & &
\end{tabular}

\begin{tabular}{|l|l|l|l|l|l|l|}
\hline Good & 82 & 29 & 35.5 & $24.9-45.8$ & 2.36 & 0.31 \\
\hline $\begin{array}{l}\text { Use of } \\
\text { harness }\end{array}$ & & 94 & 32.1 & $26.7-37.5$ & & \\
\hline $\begin{array}{l}\text { For one } \\
\text { mule }\end{array}$ & 293 & 38 & 34.9 & $25.9-43.9$ & 0.28 & 0.6 \\
\hline $\begin{array}{l}\text { For } \\
\text { mules }\end{array}$ & 109 & 97 & 33.3 & $27.9-38.8$ & & \\
\hline $\begin{array}{l}\text { Wound } \\
\text { before }\end{array}$ & 291 & 35 & 31.5 & $22.8-40.2$ & 0.12 & 0.73 \\
\hline Yes & 111 & & & &
\end{tabular}

Table 1: Prevalence of epizootic lymphangitis in cart-mules and association with different risk factors. $\mathrm{EP}=$ Epizootic lymphangitis.

The characteristic lesion of EL (nodular, ulcerative pyogranulomatous which undergo alternating eruption and granulation) were found distributed on different parts of the body. However, the lesions were detected more frequently on the fore and hind legs following the lymphatic lines (Table 2).

\begin{tabular}{|l|l|l|}
\hline Body parts & Frequency & Percentage \\
\hline Perineum & 2 & 1.52 \\
\hline Back & 3 & 2.27 \\
\hline Inguinal area & 9 & 6.82 \\
\hline Neck region & 13 & 9.85 \\
\hline $\begin{array}{l}\text { Lymphatic lines of the } \\
\text { legs }\end{array}$ & 105 & 79.6 \\
\hline Total & 132 & 100 \\
\hline
\end{tabular}

Table 2: Bodily distribution of epizootic lymphangitis lesions in the affected mules.

During the course of the study the cart-mules owners/drivers were asked if they give rest for mules affected with EL. Accordingly, about $52 \%$ of the cart owners indicated that they allowed mules to get rest for one day, $10 \%$ for two days and $4 \%$ for three or more days per week following the development of the characteristic lesion of the disease. However, $34 \%$ of the cart owners responded that they didn't allow the sick mule to get rest even for a single day. Moreover, 23 respondents mentioned that they abandoned chronically affected mules outdoors for scavengers because of lack of promising treatment and offensive odor arising from the lesion.

\section{Discussion}

There is paucity of information on the prevalence of EL in mules both locally and globally. Perhaps this may be due to the fact that mules are considered resistant or less susceptible to the disease [17]. However, observation of a high prevalence $(32.8 \%)$ of EL in mules in the current study suggests that the disease is very important in this species that needs due attention. Also, this is the second field study in Ethiopia that disproved the assumption that mules are resistant to the disease. 
Page 3 of 4

There is only a single EL study in mules in the country [11] in which a prevalence of $21 \%$ reported in cart-mules in Bako and Ejaji towns, Western Ethiopia. The prevalence documented in the current study is considerably higher than the previous report. This variation between the two studies could be attributed to differences in the climatic condition, season of the study and level of attention given for the disease. The current finding is also higher than average prevalence reports in horses from different parts of Ethiopia which range from $18.8 \%$ to $26.2 \%[6,7,10,18]$. Regarding to the distribution of EL in Ethiopia, previous researchers concluded that the disease is endemic in hot, humid areas with an altitude ranging from 1500 to 2300 m.a.s.l and few or no cases were detected in dry and windy areas, and in very cold climate areas of the country [6]. Furthermore, it has been reported that the prevalence of the disease is significantly associated with average annual temperature, altitude, tick infestation and horse population in an area, but not with mean annual rainfall [6,11]. Gilbert [19] stated that warm and moist environmental conditions allow the organism to survive in the soil for months.

In the present study, the characteristic lesions of EL were detected more frequently on the front and hind limbs following the lymphatic lines, and less frequently on the neck, inguinal, back and perineum areas in that order. Frequent exposure to injury through chaffing of legs to each other and trauma caused by harnessing may act as predisposing factor. The widely used harnesses, which have rigid and rough edges, increase the friction and wounding of the body of horses or mules $[6,20]$. The clinical presentation and distribution of EL lesions observed in the current study is in agreement with previous reports in horses and mules $[4,7,10,11,21,22]$.

The current study indicated that a considerable proportion (34\%) of cart-mule owners do not let mules affected with EL off work. This condition may weaken the immunity of the animals and worsen the severity of the lesions. Moreover, the practice of abandoning chronically infected animals outdoor by some of the cart-mule owners may lead to spread of the disease to unaffected mules and horses through direct contact and flies.

In this study, none of the risk factors considered were found to have a significant effect on the prevalence of the disease. Nonetheless, largescale epidemiological cohort studies are required to provide further evidence on these.

\section{Conclusion}

The present study has revealed a high prevalence of EL in cartmules. Carts are a means of survival for a significant number of families in the area and are probably the only means of living for most. Moreover, they provide the only affordable transportation service for goods to and from construction sites, flour mills and market places. With this high prevalence, it is clear that the disease can have a devastating impact on the income of poor families due to morbidity and mortality of abandoned mules. Thus, early detection of the disease and treatment with the available drugs, and restriction of movement of positive cases is recommended. Furthermore, the use of less traumatic harness and raising the awareness of equine owners towards the disease should be considered. Also, future studies are required to find out the factors predisposing mules to EL.

\section{Conflicts of Interest}

The authors declare that they have no conflicts of interest.

\section{Authors' Contributions}

DM collected the data and did the laboratory work. BM designed the study, supervised data collection and lab works, and drafted the manuscript. RA analyzed the data and critically and substantially revised the manuscript. All authors read and approved the final manuscript.

\section{Acknowledgements}

The authors would like to thank Bahir Dar regional veterinary laboratory for provision of necessary laboratory materials during the study. Dr. Gebreyesus Mekonen and the technical staffs at Bacteriology department are duly acknowledged for their invaluable guidance and support. We are also grateful to all Bahir Dar donkey sanctuary project staffs for their provision of transport and other materials during the data collection time.

\section{References}

1. Radostits MO, Gay CC, Hinchcliff KW, Constable PD (2007) Veterinary Medicine. A text book of the disease of cattle, horses, sheep, pigs and goats. 10th edn. Spain, Saunders Ltd., p: 1479.

2. Scantlebury C, Reed K (2009) Epizootic Lymphangitis. In: Mair TS, Hutchinson RE (eds.), Infectious diseases of the horse. EVJ Ltd, Fordham, Cambridge shire, United Kingdom, pp: 397-406.

3. Jones K (2006) Epizootic lymphangitis: The impact on subsistence economies and animal welfare. Vet J 172: 402-404.

4. Ali-Ani KT (1999) Epizootic lymphangitis in horses: a review of the literature. Rev Sci Tech 18: 691-699.

5. Singh T (1965) Studies on epizootic lymphangitis I. Mode of infection and transmission of equine histoplasmosis (epizootic lymphangitis). Indian J Vet Sci 35: 102-110.

6. Ameni G (2006) Preliminary trial on the reproducibility of epizootic lymphangitis through experimental infection of two horses. Vet J 172: 553-555.

7. Ameni G, Siyoum F (2002) Study on histoplasmosis (epizootic lymphangitis) in cart-horses in Ethiopia. J Vet Sci 3: 135-139.

8. Ameni G, Tilahun G (2003) Preliminary laboratory and field evaluation of Endod for treatment of epizootic lymphangitis. Bull Anim Health Prod Afr 51: 153-162.

9. Endebu B, Roger F (2003) Comparative studies on the occurrence and, distribution of epizootic lymphangitis and ulcerative lymphangitis in Ethiopia. Int J App R Vet Med 1: 1-8.

10. Asfaw R, Pal M, Ameni G (2012) Prevalence of Epizootic Lymphangitis in Cart Horses in Southwest Shewa of Oromia Region, Ethiopia. Int J Livest Res 2: 146-151.

11. Ameni G, Terefe W (2004) A cross-sectional study of epizootic lymphangitis in Cart- mules in western Ethiopia. Prev Vet Med 66: 93-99.

12. Solomon W, Abebe W (2007) Prevalence study of ruminant fasciolosis in areas adjoining upper Blue Nile Basin, northwestern Ethiopia. Ethiop Vet J 11: 67-81.

13. Bahir Dar Zuria Wereda Agricultural and Rural Development Office (2004).

14. Svendsen ED (1997) Parasites Abroad: The professional hand book of the donkey. 3rd edn. Whittet books, London, UK, pp: 227-38.

15. Carter GR, Chengappa MM, William G (1991) Essential of Veterinary bacteriology and mycology. 4th edn. Lea and Febinger, Philadelphia, p: 264.

16. Quinn PJ, Carter ME, Markey B, Carter GR (2002) Clinical Veterinary Microbiology. Mosby International Ltd, London, pp: 456-458.

17. Al-Ani FK, Al-Delaimi AK (1986) Epizootic lymphangitis. Pakistan Vet J 6: $96-100$. 
Citation: Meselu D, Abebe R, Mekibib B (2018) Prevalence of Epizootic Lymphangitis and Bodily Distribution of Lesions in Cart-Mules in Bahir Dar Town, Northwest Ethiopia. J Vet Sci Technol 9: 509. doi:10.4172/2157-7579.1000509

Page 4 of 4

18. Jagema T, Jarso D (2016) Study on Epidemiology and Socioeconomic Impact of Epizootic Lymphangitis in Carthorses in Southwestern Shoa. J Vet Sci Res 1: 000114 .

19. Gilbert RO (1998) Foreign Animal Disease. United States Animal Health Association, Richmond, Virginia, pp: 201-206.

20. Gabal MA, Hennager S (1982) Study on the survival of Histoplasma farciminosum in the environment. Mykosen 26: 481-487.
21. Rippon JW (1988) Medical Mycology. 3rd edn. WB Saunders Company, Philadelphia, p: 417.

22. World Animal Health Organization (OIE) (2008) Epizootic lymphangitis. In OIE Terrestrial Manual. 